\footnotetext{
${ }^{1}$ College of Animal Science and Technology and ${ }^{2}$ The National Laboratories for Agrobiotechnology, China Agricultural University, Beijing, China
}

MIN CHEN ${ }^{1}$, AIGUO WANG ${ }^{1}$, JINLIAN FU ${ }^{1}$ and NING LI $^{2}$

\title{
Different allele frequencies of MC4R gene variants in Chinese pig Breeds*
}

\begin{abstract}
A missense variant of the porcine melanorcortin-4 receptor gene (MC4R) is associated with fatness and growthrelated traits in pigs. The single nucleotide change of MC4R gene can be identified by TaqI PCR-RFLP. We checked the variation in nine Chinese native pig breeds, four pig breeds from France, together with a F2 population originating from a cross between Landrace and Lantang. We also analyzed the relationship of MC4R genotypes with effects on variation in growth and carcass-related traits in the F2 population of 111 animals. We found superiority of BB individuals for several related traits, such as age at $100 \mathrm{~kg}$ weight, average backfat, etc. The results implicated the potential use of MC4R gene as a new genetic marker for the control of economically important growth and carcass traits in pigs.
\end{abstract}

Key Words: pigs, MC4R gene, PCR-RFLP, TaqI, slaughter characteristics

\section{Zusammenfassung}

Titel der Arbeit: Unterschiedliche Allelfrequenzen für MC4R Genvarianten bei chinesischen Schweinerassen

Eine missense Variante des porzinen Melanorcortin-4 Rezeptor Genes (MC4R) ist assoziiert mit Fett- und Wachstumsmerkmalen bei Schweinen. Die Veränderung des betreffenden Nukleotids des MC4R Genes kann durch TaqI PCR-RFLP nachgewiesen werden. Die Genotypen wurden in neun chinesischen und vier französischen Rassen bestimmt. Die Beziehung zwischen MC4R Genotypen und Wachstums- und Schlachtkörpermerkmalen wurde an 111 F2 Tieren untersucht. BB Tiere waren in Merkmalen wie Alter bei 100 kg Gewicht, Rückenspeckdicke usw. überlegen. Das MC4R Gen könnte als genetischer Marker für ökonomisch wichtige Merkmale eine Rolle spielen.

Schlüsselwörter: Schwein, MC4R Gen, PCR-RFLP, TaqI, Schlachtmerkmale

\section{Introduction}

Peptides involved in the hypothalamic regulation of feed intake comprise neuropeptide Y, Leptin, CRH, propiomelanorcortin (and derivatives). Their role and that of their respective receptors in the energy metabolism has been elaborated by KAIYALA (1995), CHRISTOPH (1997), XIE et al. (1999) and KULIG et al. (2001).

The melanorcortin-4 receptor gene (MC4R) is involved in regulation of feeding behavior and body weight in humans and mice. The link between the melanocortinergic system and body weight is evident in the agouti mouse model of genetic obesity. Not only does disruption of the gene encoding this receptor lead to obesity in mice (HUSZER et al., 1997), but interactions between MC4R and leptin signalling pathways contribute to the link between body weight and feed intake (ZEMEL, 1998). Several mutations including frameshift and nonsense ones are associated with dominantly inherited obesity in human (VAISSE, 1998; YEO et al., 1998). In human other missense mutations were identified (GOTODA, 1997; 
HINNEY, 1999). A MC4R missense mutation is significantly associated with obesityrelated traits in four different commercial lines of pigs derived from European/American breeds (KIM et al.,2000).

\section{Materials and Methods}

The pig breeds used in the study included: four pig breeds from France Hybrid: Pietrain, Synthetic, Large White and Landrace (Beijing Breeding Swine Center); nine Chinese native pig breeds (The National Laboratories for Agrobiotechnology, China Agricultural University): Jinhua (Zhejiang Province), Min (Heilongjiang Province), Erhualian (Jiangsu Province), Xiang (Guizhou Province), Bamei (Qinghai Province), Jiangquhai (Jiangsu Province), Luchuan (Guangxi Zhuang Autonomous Region), Guangdong Large Black-White (Guangdong Province) and Neijiang (Sichuan Province), and a F2 population (South China Agricultural University) of 111 animals originating from a cross between Landrace and Lantang (Guangdong Province).

The primer pairs were from the pig-specific primers released by KIM (1999). The PCR fragment was about 226bp.

Forward primer: 5' - TAC CCT GAC CAT CTT GAT TG -3'

Reverse primer: 5'- ATA GCA ACA GAT GAT CTC TTT G -3'.

The PCR reaction was performed using 100-500ng of porcine genomic DNA, $200 \mu \mathrm{M}$ each dNTP, $1.5 \mathrm{mM} \mathrm{MgCl}_{2}, 0.5 \mu \mathrm{l}$ Taq polymerase, $10 \mathrm{pM}$ of each primer and $1 \times \mathrm{PCR}$ buffer in a $25 \mu \mathrm{l}$ final volume. The PCR profile included $5 \mathrm{~min}$ at $94^{\circ} \mathrm{C}$; 35 cycles of 30 $\mathrm{s}$ at $94^{\circ} \mathrm{C}, 30 \mathrm{~s}$ at $62^{\circ} \mathrm{C}, 30 \mathrm{~s}$ at $72^{\circ} \mathrm{C}$; and a final $7-m i n$ extension at $72^{\circ} \mathrm{C}$ in a Gene Amp PCR System 9700/9600/2400 (Perkin Elmer).

For confirming whether the reported single base change existing in all the detected breeds, the PCR product was digested with TaqI and incubated overnight at $65^{\circ} \mathrm{C}$. The digested fragments were separated by electrophoresis in a $4 \%$ agarose gel.

We cloned PCR fragments of homozygotes (AA, BB) from several individuals of different breeds into a T-vector which were then transformed into $E$. coli strain DH5 $\alpha$. DNA sequence analysis was performed with an automated fluorescent sequencer (ABI377, Perkin Elmer) and dye terminators.

In the F2 population of 111 animals, we analyzed the relationship between the MC4R polymorphism and growth and obesity-related: age at 100kg weight (Days), ham circle (HC), body length (BL), rear quarters weight (RW), backfat (probed, BF), average carcass backfat (ABF), fore lean weight (FLW), middle lean weight (MLW), rear lean weight (RLW), dressing percentage (DP), lean rate (LR), right carcass weight (RCW), and left carcass weight (LCW).

GLM (General Linear Models) of SAS (6.12 version) was used for processing the data. When measured, the average weight was $95.4 \mathrm{~kg}$. The data are normalized for fixed effect of sex. The traits were submitted to a covariance analysis with covariate BW (body weight):

$$
\mathrm{y}_{\mathrm{ijk}}=\mu+\mathrm{G}_{\mathrm{i}}+\mathrm{b} * \mathrm{BW}_{\mathrm{ij}}+\mathrm{e}_{\mathrm{ijk}}
$$

where $y_{i j k}$ is the observed value; $\mu$ is the population mean value; $G_{i}$ is fixed effect of the $i^{\text {th }}$ genotype of MC4R; $e_{i j}$ is the random residual effect; $b$ is the regression coefficient on body weight. 


\section{Results}

The PCR fragment was about 226bp. The TaqI digestion of the PCR produced fragments of 156 and 70bp in allele A vs 226bp in allele B. The heterozygous genotype has fragments of both allele $\mathrm{A}$ and allele $\mathrm{B}$ (Fig. 1).

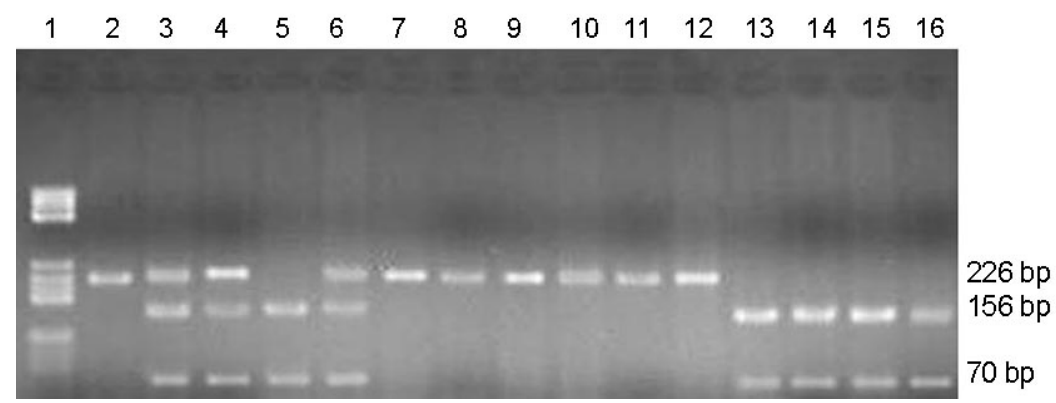

Fig.1: TaqI digestion of the PCR product of MC4R gene, analyzed by agarose-gel electrophoresis (4\%) (TaqI Veränderung des PCR Produktes des MC4R Gens, nachgewiesen mittels Agarose-Gel Elektrophorese (4\%))

Lane 1: molecular marker, PBR322/Hae III; Lane5, 13-16: allele A produced 156 and 70bp fragments; Lane2,7-12:allele B produced 226bp fragment; Lane3,4,6: the heterozygote $(\mathrm{AB})$ has both allele A and B fragments (226bp+156bp+70bp)

The multiple alignments of the sequences identified the same single nucleotide substitution ( $\mathrm{G} \rightarrow \mathrm{A}$; Fig. 2) situated in the TaqI recognition site. The polymorphism revealed a missence mutation that replaces aspartic acid (GAU) with asparagine (AAU) at the position identical to amino acid 298 of pig MC4R protein. A TaqI recognized sequence ( $\mathbf{T} \downarrow \mathbf{C G} \mathbf{A})$ disappeared in the mutant (TCAAA). We cloned the heterozygotes $(\mathrm{AB})$ and the homozygotes (AA, BB) from different randomly selected breeds, and then sequenced the two different homozygotes, one from homozygote clones and the other from the heterozygote clones identified by TaqI digestion. The results confirmed the single base mutation mentioned above.
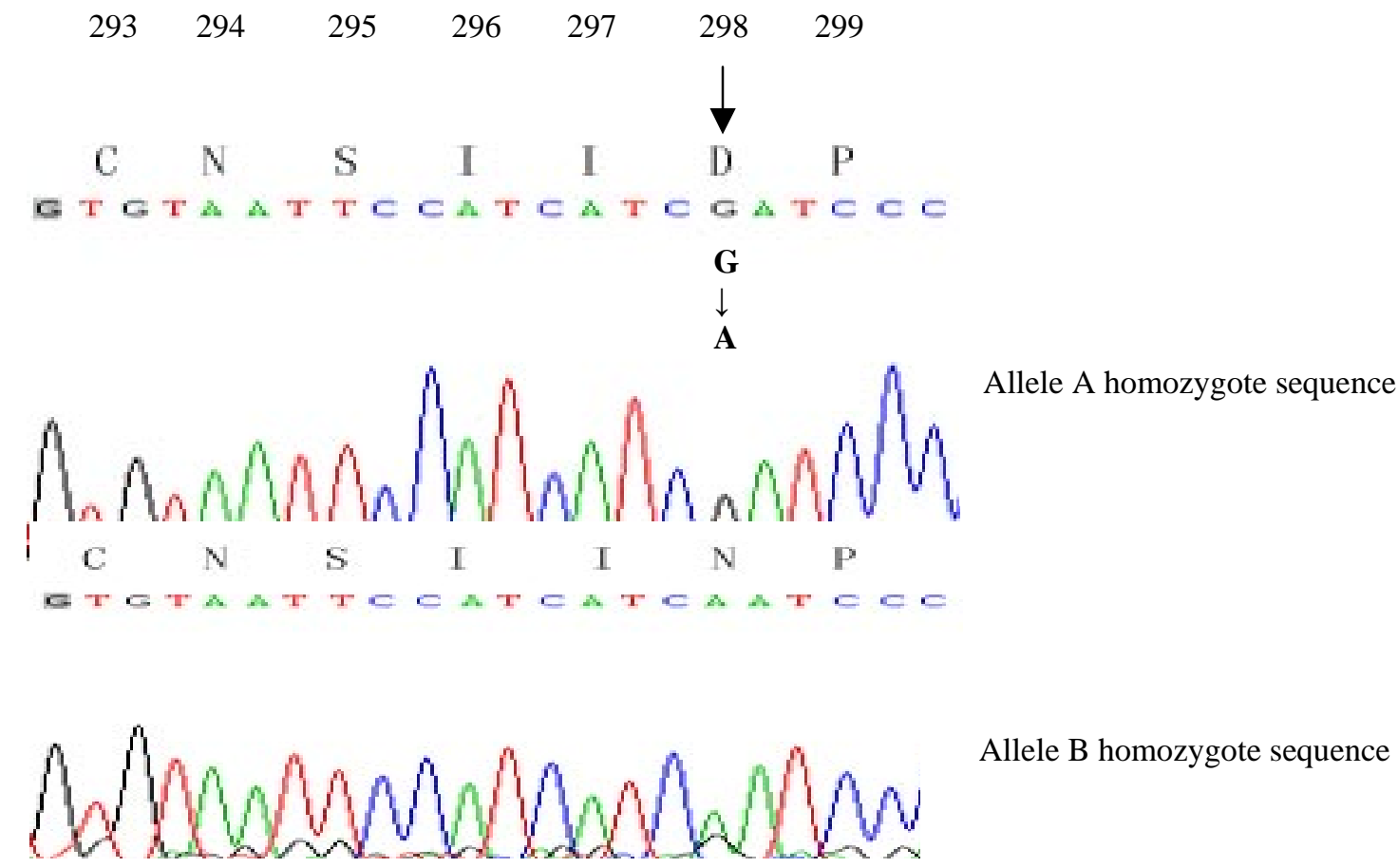

Allele B homozygote sequence

Fig. 2: Partial sequences comparison between the two homozygotes of the porcine MC4R gene (Vergleich der Teilsequenzen zwischen den zwei Homozygoten des porcinen MC4R Gens)

Notations: The $\mathrm{G} \rightarrow$ A substitution of the PCR product is marked with an arrow. The amino acid translation shows an amino acid substitution at code 298 that replaces aspartic acid (GAU) with asparagine (AAU). 
Allele frequencies were estimated from genotyping of four French breeds, nine Chinese and a F2 population originating from a cross between Landrace and Lantang (Table 1).

Table 1

The gene frequency of MC4R in different pig breeds (Frequenzen des MC4R Gens bei verschiedenen Schweinerassen)

\begin{tabular}{ccccccc}
\hline Breeds & $\begin{array}{c}\text { Numbers of } \\
\text { observations }\end{array}$ & & Genotypes & \multicolumn{2}{c}{ Gene frequency } \\
\hline Pietrain & & AA & AB & BB & A & B \\
Synthethic & 22 & 13 & 8 & 1 & 0.773 & 0.227 \\
Landrace & 31 & 0 & 7 & 24 & 0.113 & 0.887 \\
Large White & 39 & 10 & 21 & 8 & 0.526 & 0.474 \\
Min & 44 & 0 & 2 & 42 & 0.023 & 0.977 \\
Jinhua & 40 & 40 & 0 & 0 & 1 & 0 \\
Erhualian & 34 & 35 & 0 & 0 & 1 & 0 \\
Xiang & 65 & 64 & 1 & 0 & 0.992 & 0.008 \\
Bamei & 45 & 0 & 26 & 19 & 0.289 & 0.711 \\
Jiangquhai & 25 & 14 & 8 & 3 & 0.72 & 0.28 \\
Luchuan & 42 & 32 & 10 & 0 & 0.881 & 0.119 \\
Guangdong Large Black-White & 26 & 1 & 22 & 3 & 0.462 & 0.538 \\
Neijiang & 36 & 0 & 36 & 0 & 0.5 & 0.5 \\
F2 (Landrace $\times$ Lantang) & 32 & 7 & 25 & 0 & 0.609 & 0.391 \\
\hline
\end{tabular}

Table 2

Means and standard difference, least squares means and standard errors for different genotypes of MC4R in different traits (Mittelwert und Standardabweichung sowie least squares means und Standardfehler unterschiedlicher MC4R Genotypen bei verschiedenen Merkmalen)

\begin{tabular}{ccccc}
\hline & & & MC4R & \\
\cline { 3 - 4 } Traits & $\overline{\mathrm{X}} \pm \mathrm{SD}$ & $\mathrm{AA}(30)$ & $\mathrm{AB}(62)$ & $\mathrm{BB}(19)$ \\
& & $\overline{\mathrm{X}} \pm \mathrm{SE}$ & $\overline{\mathrm{X}} \pm \mathrm{SE}$ & $235.07 \pm 10.70^{\mathrm{b}}$ \\
\hline $\mathrm{DAYS}$ & $249.54 \pm 47.67$ & $267.89 \pm 8.51^{\mathrm{a}}$ & $245.03 \pm 5.97^{\mathrm{ab}}$ & $23.1 \pm 1.5^{\mathrm{b}}$ \\
$\mathrm{BF} / \mathrm{mm}$ & $26.7 \pm 6.9$ & $28.7 \pm 1.2^{\mathrm{a}}$ & $26.9 \pm 0.9^{\mathrm{a}}$ & $26.3 \pm 1.7^{\mathrm{b}}$ \\
$\mathrm{ABF} / \mathrm{mm}$ & $28.8 \pm 7.4$ & $30.3 \pm 1.3^{\mathrm{a}}$ & $28.9 \pm 0.9^{\mathrm{ab}}$ & $6.30 \pm 0.14^{\mathrm{b}}$ \\
$\mathrm{FLW} / \mathrm{kg}$ & $6.13 \pm 0.71$ & $5.96 \pm 0.11^{\mathrm{a}}$ & $6.15 \pm 0.08^{\mathrm{ab}}$ & $70.09 \pm 3.21^{\mathrm{b}}$ \\
$\mathrm{HC} / \mathrm{cm}$ & $74.99 \pm 14.11$ & $78.99 \pm 2.56^{\mathrm{a}}$ & $74.56 \pm 1.78^{\mathrm{ab}}$ & $9.50 \pm 0.15$ \\
$\mathrm{RW} / \mathrm{kg}$ & $9.49 \pm 0.84$ & $9.58 \pm 0.12$ & $9.44 \pm 0.08$ & $4.83 \pm 0.16$ \\
$\mathrm{MLW} / \mathrm{kg}$ & $4.70 \pm 0.72$ & $4.62 \pm 0.12$ & $4.70 \pm 0.09$ & $5.24 \pm 0.13$ \\
$\mathrm{RLW} / \mathrm{kg}$ & $5.23 \pm 0.67$ & $5.23 \pm 0.10$ & $5.22 \pm 0.07$ & $35.21 \pm 0.36$ \\
$\mathrm{RCW} / \mathrm{kg}$ & $34.98 \pm 2.54$ & $34.64 \pm 0.29$ & $35.08 \pm 0.20$ & $34.83 \pm 0.40$ \\
$\mathrm{LCW} / \mathrm{kg}$ & $34.83 \pm 2.71$ & $34.58 \pm 0.32$ & $34.95 \pm 0.22$ & $73.21 \pm 0.69$ \\
$\mathrm{DP} / \%$ & $73.16 \pm 2.99$ & $72.50 \pm 0.55$ & $73.47 \pm 0.38$ & $108.33 \pm 3.78$ \\
$\mathrm{BL} / \mathrm{cm}$ & $112.83 \pm 16.79$ & $115.72 \pm 3.01$ & $112.81 \pm 2.09$ & $49.54 \pm 0.98$ \\
$\mathrm{LR} / \%$ & $48.70 \pm 4.09$ & $48.37 \pm 0.64$ & $48.60 \pm 0.55$ & \\
\hline
\end{tabular}

Notations: 1) explanation of abbreviations: age at 100kg weight (Days), backfat (probed, BF), average carcass backfat (ABF), fore lean weight (FLW), ham circle (HC), rear quarters weight (RW), middle lean weight (MLW), rear lean weight (RLW), right carcass weight (RCW), left carcass weight (LCW), dressing percentage (DP), body length (BL), lean rate (LR).

2) In the same row's superscripts, different letters denoted significant difference $(\mathrm{P}<0.05)$; the same letters denotes no significant difference existed $(\mathrm{P}>0.05)$

Among the 111 F2 animals from Landrace $\times$ Lantang, analyses of variance procedures in a SAS program were used. We found significant association of the MC4R genotypes with several traits. The animals homozygous for allele B had significantly 
few days at $100 \mathrm{~kg}$ weight (Days), less backfat (probed, BF), less average carcass backfat $(\mathrm{ABF})$, more fore lean weight (FLW) $(\mathrm{P}<0.05$, Table 2$)$.

\section{Discussion}

We found the mutation of the MC4R gene in most of the native breeds. There was only allele A (156bp+70bp) in Min and Jinghua. The gene frequencies in different pig breeds did not show the same trend. Guangdong large black-white has a 100 percent of heterozygous animals. It seemed to be not a really random samplings because the animals originated from a closed population.

Analyses of F2 population demonstrated that the porcine MC4R missense mutation was significantly associated with several performance traits. Allele A representing Asp298, the well-conserved amino acid within other MCR subtypes and in MC4R of other species, was associated with more backfat thickness of probed and carcass, slower-growing animals, and less fore lean weight. All those implied the superiority of BB individuals on growth and carcass performance.

The values of different genotypes were significantly different, for days at $100 \mathrm{~kg}$ (DAYS, $A A>A B>B B$ ), fore lean weight (FLW, BB $>A B>A A$ ), backfat probed (BF, $A A>A B>B B)$, and average carcass backfat ( $A B F, A A>A B>B B)$. Other related traits without significant difference showed the superiority of $\mathrm{BB}$ individuals too ( $\mathrm{BB}>$ $\mathrm{AA})$, such as middle lean weight (MLW), right carcass weight (RCW), rear lean weight (RLW), left carcass weight (LCW), dressing percentage (DP), and lean rate (LR). All showed that the BB individuals grow faster with thinner backfat, and the BB genotype had better performances on most growth and carcass traits.

However, AA genotypes showed better performance ( $A A>A B>B B$ ) on ham circle (HC), with significant difference, and body length (BL) without significant difference. And these may be due to the small sample size.

In pig breeding, selection on growth and carcass traits has been of great importance because of costs associated with feeding and consumer preference for lean meat. Efficient genetic improvement in these quantitative traits may be augmented through the use of marker-assisted selection (MAS) by use of high-density genetic maps(DEKKERS and VAN ARENDONK, 1998; ROTHCHILD, 1999). Only a limited list of individual genes with major effects on growth and performance traits have been reported in commercial populations(FUJI et al., 1991; JEON et al., 1999; NEZER et al., 1999). The role of MC4R in growth and carcass related traits suggested it may be an important genetic marker for the related traits of pigs. It may be related with other obesity-related traits.

For the effect of MC4R variant, we should enlarge the sample size for further analysis.

\section{Acknowledgements}

The authors thank Prof. YAOSHENG CHEN, South China Agricultural University and Beijing Breeding Swine Center for collecting samples.

\section{References}

CHRISTOPH, A.M.:

Molecular insights into the regulation of energy intake and expenditure. European Journal of Endocrinology 137 (1997), 20-21

DEKKERS, J.C.M.; VAN ARENDONK, J.A.M. 
Optimizing selection for quantitative traits with information on an identified locus in outbred populations. Genetical Research 71 (1998) 3, 257-275

FUJI, J.; OTSU, K.; ZORZATO, F.; DE LEON, S.; KHANNA, V.K.; WEILER, J.E.; O’BRIEN, P.J.; MACLENNO; D.H.:

Identification of a mutation in porcine ryanodine receptor associated with malignant hyperthermia. Science 253 (1991), 448-451

GOTODA, T.:

Molecular screening of the human melanocortin-4 receptor gene :identification of a missense variant showing no association with obesity, plasma glucose, or insulin. Diabetologia 40 (1997), 976-979

HINNEY, A.:

Several mutations in the melanocortin-4 receptor gene including a nonsense and a frameshift mutation associated with dominantly inherited obesity in humans. Journal of Clinical Endocrinology and Metabolism 84 (1999), 1483-1486

HUSZER, D.; LYNCH, C.A.; FAIRCHILD-HUNTRESS, V.; DUNMORE, J.H.; FANG, Q.; BERKEMEIER, L.R.; GU, W.; KESTERSON, R.A.; BOSTON, B.A.; CONE, R.D.; SMITH, F.J.; CAMPFIELD, L.A.; BURN, P.; LEE, F.:

Targeted disruption of the melanocortin 4 receptor results on obesity in mice. Cell 88 (1997) 1, 131-141

JEON, J.T.; CARLBERG, O.; TORNSTEN, A.; GIUFFRA, E.; AMARGER, V.; CHARDON, P.;

ANDERSSON-EKLUND, L.; ANDERSSON, K.; HANSSON, I.; LUNDSTROM, K.; ANDERSSON, L.:

A paternally expressed QTL affecting skeletal and cardiac muscle mass in pigs map to the IGF2 locus.

Nature Genetics 21 (1999), 157-158

KAIYALA, K.J.:

New model for the regulation of energy balance and adiposity by the central nervous system. American KIM, K.S.: Journal of Clinical Nutrition 62 (1995) 5, Suppl., 1123S-1134S

Mapping and Investigation of Novel Candidate for Fatness, Growth, and Feed Intake in the Pig. Breeding and Physiology 137 (1999), 20-21

KIM, K.S.; LARSEN, N.J.; SHORT, T.:

A missense variant of the porcine melanocortin-4 receptor (MC4R) gene is associated with fatness, growth, and feed intake traits. Mammalian Genome 11 (2000), 131-135

KULIG, H.; GRZESIAK, W.; SZATKOWSKA, I.:

Effect of leptin gene polymorphism on growth and carcass traits in pigs. Arch. Tierz., Dummerstorf 44 (2001) 3, 291-296

NEZER, C.; MOREAU, L.; BROUWERS, B.; COPPIETERS, W.; DETILLEUX, J.; HANSET, R.; KARIM, L.;

KVASZ, A.; LEROY, P.; GEORGES, M.:

An imprinted QTL with major effect on muscle mass and fat deposition maps to the IGF2 locus in pigs. Nature Genetics 21 (1999), 155-156

ROTHCHILD, M.F.:

Advances in pig genomics and industry applications. AgBiotechNet 1 (1999), 1-8

VAISSE, C.:

A frameshift mutation in human MC4R is associated with a dominant form of obesity. Nature Genetics, 20 (1998) 2, 113-114

XIE, C.; ALBRECHT, E.; WEGNER, J.; BROCKMANN, G.; KAZALA, CH.; WESELAKE, R.J.; ENDER, K.: Leptin, a palatability molecule? - A review. Arch. Tierz., Dummerstorf 42 (1999) 2, 191-199

YEO, G.S.; FAROOQI, I.S.; AMINIAN, S.; HALSALL, D.J.; STANHOPE, R.G.; O’RAHILLY, S.:

A frameshift mutation in MC4R associated with dominantly inherited human obesity. Nature Genetics, 20 (1998) 2, 111-112

ZEMEL, M.B.:

Agouti/melanocortin interaction with leptin pathways in obesity. Nutrition Reviews 56 (1998), 271-281

Received: 2004-03-18

Accepted: 2004-08-09

Corresponding author

Prof. Dr. AIGUO WANG

College of Animal Science and Technology

China Agricultural University

Beijing 100094

China

E-Mail: agwang@cau.edu.cn 